\title{
Oxidative Conversion of Hexane to Olefins-Influence of Plasma and Catalyst on Reaction Pathways
}

\author{
C. Boyadjian • A. Ağıral • J. G. E. Gardeniers • L. Lefferts • \\ K. Seshan
}

Received: 20 July 2010/Accepted: 16 December 2010/Published online: 3 February 2011

(C) The Author(s) 2011. This article is published with open access at Springerlink.com

\begin{abstract}
An integrated plasma- $\mathrm{Li} / \mathrm{MgO}$ system is efficient for the oxidative conversion of hexane. In comparison to the $\mathrm{Li} / \mathrm{MgO}$ catalytic system, it brings considerable improvements in the yields of light olefins $\left(\mathrm{C}_{2}^{\bar{E}}-\mathrm{C}_{5}^{\overline{\bar{y}}}\right)$ at relatively low temperatures indicating synergy from combination of plasma and catalyst. The study on the influence of temperature on the performance of the integrated plasma- $\mathrm{Li} / \mathrm{MgO}$ system shows dominancy of plasma chemistry at the lower temperature $\left(500^{\circ} \mathrm{C}\right)$, while contribution from the catalyst both in hexane activation and in enhancing olefin formation becomes significant at the higher temperature $\left(600^{\circ} \mathrm{C}\right)$. At $500^{\circ} \mathrm{C}$ significant amount of acetylene formation is observed. This is minimized at $600^{\circ} \mathrm{C}$ at oxygen depleting conditions.
\end{abstract}

Keywords Barrier discharge - Plasma - Hexane - Oxygen · Oxidative conversion · Olefins $\cdot$ Oxicracking $\cdot \mathrm{Li} / \mathrm{MgO}$

\section{Introduction}

Catalytic oxidative cracking of naphtha is conceptually a potential alternative process to steam cracking. Both the presence of oxygen and catalyst are beneficial for facilitating cracking reactions at lower temperatures. Reactions in presence of oxygen are exothermic, thus internally provide heat for endothermic cracking reactions $(\mathrm{C}-\mathrm{C}, \mathrm{C}-\mathrm{H}$ bond cleavage $)$. Presence of catalyst stimulates $\mathrm{C}-\mathrm{C}, \mathrm{C}-\mathrm{H}$ bond scission in the alkane and induces cracking at lower temperatures than in the homogeneous phase. The development of an efficient oxidation catalyst that minimizes combustion, however, remains a challenge. Recent studies on oxidic catalysts with no facile red-ox properties have shown tremendous

C. Boyadjian · L. Lefferts · K. Seshan $(\bowtie)$

Catalytic Processes and Materials, MESA+ Institute for Nanotechnology, Faculty of Science and Technology, University of Twente, P.O. Box 217, 7500 AE Enschede, The Netherlands e-mail: k.seshan@tnw.utwente.nl

A. Ağıral · J. G. E. Gardeniers

Mesoscale Chemical Systems, IMPACT, MESA+ Institute for Nanotechnology, Faculty of Science and Technology, University of Twente, P.O. Box 217, 7500 AE Enschede, The Netherlands 
increase in olefin yields $[1,2]$. Among these is the $\mathrm{Li} / \mathrm{MgO}$ catalyst, which has been extensively studied in literature for the oxidative conversion of alkanes; oxidative coupling of methane [3,4] and oxidative dehydrogenation/cracking of ethane [5,6], propane and butane [7-11]. Unlike in the case of oxidic catalysts with red-ox properties [12], sequential combustion of olefins over $\mathrm{Li} / \mathrm{MgO}$ occurs to a minimal extent, resulting in an olefin selectivity which is almost invariant with the alkane conversion levels. Recently, we [13] reported on the performance of $\mathrm{Li} / \mathrm{MgO}$ catalyst for the oxidative conversion/cracking of hexane. The catalyst showed very good selectivity to $\mathrm{C}_{2}-\mathrm{C}_{4}$ olefins $(60 \mathrm{~mol} \%)$ at a temperature as low as $575^{\circ} \mathrm{C}$, which is much lower than temperatures used in steam crackers $\left(T \geq 800^{\circ} \mathrm{C}\right)$. Similar to what is reported in literature and our earlier studies for oxidative conversion of lower alkanes (methane [3], ethane [4-6, 12], propane [6-11] and butane [7]), we proposed hexane activation via the $\left[\mathrm{Li}^{+} \mathrm{O}^{-}\right]$sites of $\mathrm{Li} / \mathrm{MgO}$ abstracting $\mathrm{H}^{\bullet}$. The hexyl radical formed then undergoes complex radical chemistry in gas phase in presence of molecular oxygen, forming the product mixture of $\mathrm{C}_{1}-\mathrm{C}_{5}$ products, including olefins, paraffins and combustion $\left(\mathrm{CO}_{x}\right)$ products.

$\mathrm{Li} / \mathrm{MgO}$ has no cations with variable valency and unlike catalysts with red-ox properties $\left(\mathrm{Mn}^{2+3+}, \mathrm{Co}^{2+, 3+}\right)$, has lower oxidation activity. This results in relatively low hexane conversions during the oxidative cracking of hexane [13]. Kinetic results from the oxidative conversion of alkanes over the $\mathrm{Li} / \mathrm{MgO}$ show that $\mathrm{C}-\mathrm{H}$ bond splitting is the rate limiting step in these reactions [9]. Even in the presence of strong $\mathrm{H}^{\bullet}$ abstractor, e.g., $\left[\mathrm{Li}^{+} \mathrm{O}^{-}\right]$, high temperatures $\geq 550^{\circ} \mathrm{C}$ are still required to induce this step.

In an attempt to enhance the $\mathrm{H}^{\bullet}$ abstraction in the alkane, we recently investigated the oxidative conversion of propane [14, 15], ethane and methane [14] at ambient conditions in presence of plasma in a micro-reactor both in presence and absence of $\mathrm{Li} / \mathrm{MgO}$ catalyst. Indeed, in these experiments plasma induced alkane activation and alkyl radicals were formed at ambient conditions as result of electron impact collisions caused by plasma. In the case of propane plasma experiments, higher conversions were observed in the presence of $\mathrm{Li} / \mathrm{MgO}$ catalyst as compared to empty micro-reactor. This is due to enhanced plasma efficiency as result of increase in permittivity of the system, leading to increase in electron density, hence electron impact collisions [15]. The presence of $\mathrm{Li} / \mathrm{MgO}$ catalyst also resulted in enhanced selectivity to propylene. Propyl radicals, generated from propane via activation by plasma, interact with the $\left[\mathrm{Li}^{+} \mathrm{O}^{-}\right]$sites of the catalyst, where the latter abstracts a second hydrogen atom from the propyl radical forming propylene [15].

Recently, we [16] investigated the oxidative conversion of hexane in a plasma reactor in the temperature range $400-600^{\circ} \mathrm{C}$. Similar to lower alkanes, the application of plasma induced hexane and oxygen conversion at temperatures as low as $400^{\circ} \mathrm{C}$. At the lower temperatures $\left(400,500^{\circ} \mathrm{C}\right)$ coupling of formed radicals was observed leading to formation of $\mathrm{C}_{6}{ }^{+}$hydrocarbons. However, at the higher temperature $\left(600^{\circ} \mathrm{C}\right)$ cracking and lower olefins $\left(\mathrm{C}_{2}^{=}-\mathrm{C}_{4}^{=}\right)$formation became more significant. Optimum olefins yields were observed at $8 \%$ of oxygen in the feed, as increasing oxygen concentrations above this resulted in the formation of combustion products.

Although application of non-thermal plasma (plasma at ambient conditions) is more commonly reported, integrated plasma-catalytic systems at elevated temperatures, so-called plasma/catalysis have also been of continuous interest, especially for decomposition of hydrocarbons $[17,18]$. In particular, decomposition of methane to hydrogen and carbon has been investigated [19, 20]. Nozaki et al. [20], investigated steam reforming of methane using plasma with a $\mathrm{Ni} / \mathrm{SiO}_{2}$ catalyst. A strong synergistic effect and hence significant improvement in the methane conversion was observed at $400^{\circ} \mathrm{C}$. Similarly, the 
presence of catalyst downstream to plasma, during the oxidative conversion of methane [21], improved selectivities to ethylene.

In analogy to such systems, in the present work the performance of an integrated plasma-Li/MgO system for the oxidative conversion of hexane is reported. Our objective is to further enhance the yields of olefins, compared to those achieved in the plasma reactor in the absence of the catalyst. The influence of plasma on the selectivities to various products in relation to the chemistry on the surface; i.e., the role of $\mathrm{Li} / \mathrm{MgO}$ catalyst in hexane activation and controlling olefin formation, is discussed.

\section{Experimental}

Materials and Methods

Commercially available $\mathrm{Mg}\left(\mathrm{OCH}_{3}\right)_{2}$ solution in methanol (Aldrich, 6-8wt\% in methanol), $\mathrm{CH}_{3} \mathrm{OH}$ (Merck), $\mathrm{LiNO}_{3}$ (Aldrich, assay $\geq 99.99 \%$ ) were used for preparation of $\mathrm{Li} / \mathrm{MgO}$ catalysts. Sol-gel synthesized $\mathrm{Li} / \mathrm{MgO}$ catalyst used in this study was prepared according to the method described earlier by us [10].

BET surface area of the catalyst was determined with nitrogen physisorption using a Micro-metrics Tristar instrument. The samples were out-gassed in vacuum at $250^{\circ} \mathrm{C}$ for $24 \mathrm{~h}$ prior to the analysis. BET surface area of the catalyst was $82 \mathrm{~m}^{2} / \mathrm{g}$. The elemental composition of the catalyst was determined with atomic absorption spectroscopy (AAS). Li content in the catalyst was $0.86 \mathrm{wt} \%$.

\section{Catalytic Measurements}

Measurements with the integrated plasma- $\mathrm{Li} / \mathrm{MgO}$ system were carried out at atmospheric pressure and isothermal conditions in a fixed-bed reactor [16]. A quartz reactor of $4 \mathrm{~mm}$ internal diameter was used. The reactor was equipped with an internal stainless steel wire (ID $1.5 \mathrm{~mm}$ ) as high voltage electrode and an external aluminum foil as ground electrode. Plasma was generated between the high voltage wire electrode and the grounded aluminum foil around the quartz tube using $6 \mathrm{kV}$ peak AC voltage. The power supply had an output of 10 Watts maximum. The power absorbed by the plasma was calculated to be $\sim 3 \mathrm{~W}$ (180 J/min). This was evaluated using the corresponding V-Q Lessajous figures, obtained using an oscilloscope [19]. Light emission from the discharge was collected through a collimating lens placed at a $90^{\circ}$ angle to the outside of the reactor. An optical fiber was used to transmit the light to an optical emission spectrometer (HR 4000, Ocean Optics).The HR 4000 spectrometer was responsive from 200 to $1,100 \mathrm{~nm}$ with a resolution of $0.04 \mathrm{~nm}$.

Catalyst or quartz particles (300-500 mg depending on the experiment) were packed between two quartz-wool plugs in the quartz reactor according to configuration in Fig. 1a. For gas phase non-catalytic reactions, an empty reactor according to configurations in Fig. 1b, c were used. A different reactor configuration with $\mathrm{Li} / \mathrm{MgO}$ downstream to plasma (Fig. 1d) was as well investigated. Powder catalyst was pressed, crushed and sieved to particle size range of $0.4-0.6 \mathrm{~mm}$ before use. Reactions were studied at both 500 and $600^{\circ} \mathrm{C}$. The reactor was heated using an electrical furnace. The temperature of the furnace was controlled by a thermocouple placed outside the reactor tube within the isothermal zone of the tubular furnace. Total gas feed of $100 \mathrm{ml} / \mathrm{min}$ was used. This consisted of $10 \mathrm{~mol} \%$ of hexane vapor, $8 \mathrm{~mol} \%$ of oxygen and balance helium. Before each catalytic test, the catalyst was pretreated in $50 \% \mathrm{O}_{2} / \mathrm{He}(60 \mathrm{ml} / \mathrm{min})$ for $1 \mathrm{~h}$ at a temperature of 


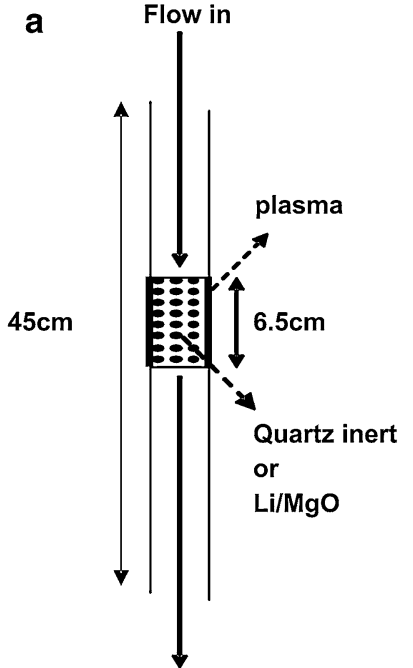

Flow out

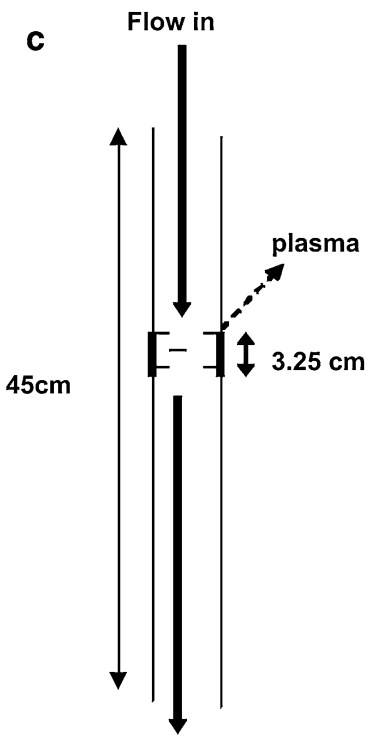

Flow out
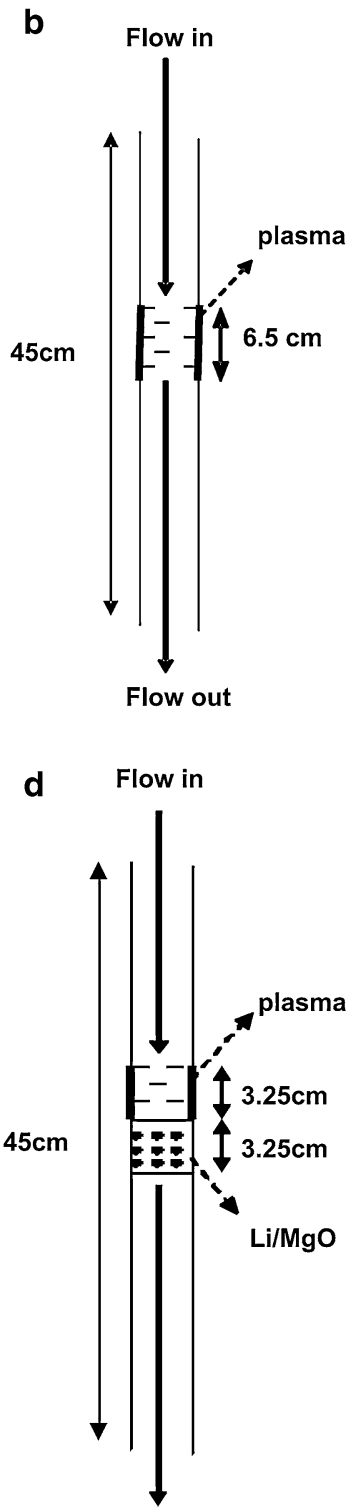

Flow out

Fig. 1 Reactor configurations used; Plasma applied to Li/MgO (P_Li/MgO) or quartz (P_Quartz) (a), plasma applied to empty reactor $\left(\mathrm{P} \_\mathrm{ER}\right)(\mathbf{b}, \mathbf{c})$, and $\mathrm{Li} / \mathrm{MgO}$ downstream to plasma zone (PB_Li/MgO) $(\mathbf{d})$

$650^{\circ} \mathrm{C}$. For analysis of the product mixture two online micro GCs were utilized. The experimental setup used for catalyst testing and analysis details are described in [13].

Hexane conversions were calculated on carbon mol basis; i.e., ( $\mathrm{C}_{6}^{\text {in }}$ moles $-\mathrm{C}_{6}^{\text {out }}$ moles $) /$ $\mathrm{C}_{6}^{\text {in }}$ moles $\times 100 \%$. The carbon balance closed between 100 and $110 \%$. Selectivity to individual products was also calculated based on the number of moles of carbon contained in the products. 


\section{Results and Discussion}

Figure 2 shows hexane conversions from the oxidative conversion of hexane both at 500 and $600^{\circ} \mathrm{C}$, (1) in an empty reactor in the absence and presence of plasma and (2) with $\mathrm{Li} / \mathrm{MgO}$ catalyst without plasma. Gas phase activation of hexane in the empty reactor and in absence of plasma, occurs via thermal cleavage of $\mathrm{C}-\mathrm{C}$ and $\mathrm{C}-\mathrm{H}$ bonds leading to radical formation and/or via collision of hexane with oxygen molecules forming hexyl $\left(\mathrm{C}_{6} \mathrm{H}_{13}^{\bullet}\right)$ and $\mathrm{HO}_{2}^{\bullet}$ radicals. The latter act as the main chain propagators in the gas phase radical chemistry $[13,16]$. At both temperatures hexane conversions in the empty reactor were almost negligible. The introduction of the catalyst however, resulted in a considerable improvement in hexane conversions. Significantly, the application of plasma enhanced hexane conversions at both temperatures.

Thus, results of hexane conversions in Fig. 2 elucidate the significant influence of both $\mathrm{Li} / \mathrm{MgO}$ catalyst and plasma on hexane activation. Temperature has also a clear effect on hexane conversions but was more significant in the case of the $\mathrm{Li} / \mathrm{MgO}$ catalyst. Details of the oxidative conversion of hexane in the presence of both (1) plasma and (2) $\mathrm{Li} / \mathrm{MgO}$ catalyst at 500 and $600^{\circ} \mathrm{C}$ are presented in sections below.

\section{Oxidative Conversion of Hexane in the Presence of Plasma}

During the oxidative conversion of hexane, we previously showed that the role of plasma was to induce both hexane and oxygen conversions via electron impact excitations. The average electron energy for the 'hexane + oxygen + helium' system, solving the Boltzmann distribution [16], was calculated to be $4.3 \mathrm{eV}$. This is sufficient to induce $\mathrm{C}-\mathrm{C}$ (bond energy $3.17 \mathrm{eV}$ ) and $\mathrm{C}-\mathrm{H}$ (bond energy $3.97 \mathrm{eV}$ ) bond scission in the hexane, and the fraction of electrons with higher energy can also cause dissociation of molecular oxygen $(\sim 6 \mathrm{eV})$. The dramatic improvement observed [16] in hexane conversions with the introduction of oxygen in the system, confirmed the existence of new routes for hexane

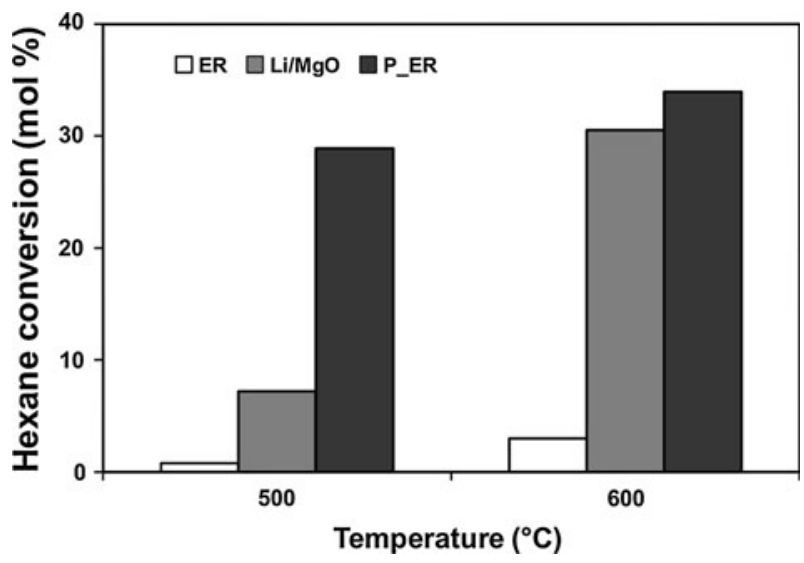

Fig. 2 Hexane conversions (1) in an empty reactor, (2) with $\mathrm{Li} / \mathrm{MgO}$ and (3) in a plasma reactor. Oxygen conversions (mol\%): At $500^{\circ} \mathrm{C} ; 4(\mathrm{ER}), 56(\mathrm{Li} / \mathrm{MgO}), 71\left(\mathrm{P} \_\mathrm{ER}\right)$ and at $600^{\circ} \mathrm{C} ; 10(\mathrm{ER}), 100(\mathrm{Li} / \mathrm{MgO})$, $100 \mathrm{~mol} \%$ (P_ER). Reaction conditions: $100 \mathrm{ml} / \mathrm{min}, 10 \%$ hexane, $8 \%$ oxygen and balance helium. WHSV (weight hourly space velocity) $=3.08 \mathrm{~h}^{-1}$ 
conversion, involving gas phase activation of oxygen by plasma. Calculation of the fractional energy dissipated in the electron impact processes leading to vibrational excitation, ionization and dissociation of both hexane and oxygen molecules showed that dissociation of these molecules is a more significant pathway [16]. Thus, in the presence of plasma the following hexane dissociation routes were proposed (2) $\mathrm{C}-\mathrm{C}, \mathrm{C}-\mathrm{H}$ bond scission by electron-impact excitation of hexane molecules (1-4) and (3) $\mathrm{C}-\mathrm{H}$ bond scission by collision of hexane molecules with $\mathrm{O}\left({ }^{3} \mathrm{P}\right)$ oxygen atoms (5) formed from electron impact excitations of molecular oxygen (6-7). Moreover, we showed previously [16], the reaction of molecular oxygen with hexyl radicals forming $\mathrm{HOO}^{\bullet}$ radicals (8). $\mathrm{HOO}^{\bullet}$ radicals act as the main chain propagators and increase the radical concentration during oxidative conversion.

$$
\begin{aligned}
& \mathrm{C}_{6} \mathrm{H}_{14}+\mathrm{e}^{-} \rightarrow \mathrm{C}_{6} \mathrm{H}_{13}^{\bullet}+\mathrm{H}^{\bullet}+\mathrm{e}^{-} \\
& \mathrm{C}_{6} \mathrm{H}_{14}+\mathrm{e}^{-} \rightarrow \mathrm{C}_{5} \mathrm{H}_{11}^{\bullet}+\mathrm{CH}_{3}^{\bullet}+\mathrm{e}^{-} \\
& \mathrm{C}_{6} \mathrm{H}_{14}+\mathrm{e}^{-} \rightarrow \mathrm{C}_{4} \mathrm{H}_{9}^{\bullet}+\mathrm{C}_{2} \mathrm{H}_{5}^{\bullet}+\mathrm{e}^{-} \\
& \mathrm{C}_{6} \mathrm{H}_{14}+\mathrm{e}^{-} \rightarrow \mathrm{C}_{3} \mathrm{H}_{7}^{\bullet}+\mathrm{C}_{3} \mathrm{H}_{7}^{\bullet}+\mathrm{e}^{-} \\
& \mathrm{C}_{6} \mathrm{H}_{14}+\mathrm{O}\left({ }^{3} \mathrm{P}\right) \rightarrow \mathrm{C}_{6} \mathrm{H}_{13}^{\bullet}+\mathrm{OH}^{\bullet} \\
& \mathrm{O}_{2}+\mathrm{e}^{-} \rightarrow 2 \mathrm{O}\left({ }^{3} \mathrm{P}\right)+\mathrm{e}^{-} \\
& \mathrm{O}_{2}+\mathrm{e}^{-} \rightarrow \mathrm{O}\left({ }^{3} \mathrm{P}\right)+\mathrm{O}\left({ }^{1} \mathrm{D}\right)+\mathrm{e}^{-} \\
& \mathrm{O}_{2}+\mathrm{C}_{6} \mathrm{H}_{13}^{\bullet} \rightarrow \mathrm{C}_{6} \mathrm{H}_{12}+\mathrm{HOO}^{\bullet}
\end{aligned}
$$

Optical emission spectrum of a $\mathrm{C}_{6} \mathrm{H}_{14}-\mathrm{He}$ mixture in plasma (Fig. 3) confirms the influence of plasma on hexane activation. Features of the electronic excitation of the $\mathrm{CH}^{\bullet}$ radical corresponding to the $\mathrm{A}^{2} \Delta \rightarrow \mathrm{X}^{2} \pi$ transition at $431.15 \mathrm{~nm}$ and bands corresponding to $\mathrm{H}^{\bullet}$ radicals $(656.05 \mathrm{~nm})(\mathrm{H} \alpha$, Balmer series) and helium $(587.61$ and $667.78 \mathrm{~nm})$ were observed. The existence of $\mathrm{CH}$ and $\mathrm{H}$ bands in the optical emission spectrum of $\mathrm{C}_{6} \mathrm{H}_{14}-\mathrm{He}$ mixture indicate the decomposition of hexane in plasma via $\mathrm{C}-\mathrm{H}$ and $\mathrm{C}-\mathrm{C}$ bond cleavage. $\mathrm{CH}^{\bullet}$ radicals in the presence of plasma are generally formed, as proposed in literature by Kado et al. [22], through the extensive dehydrogenation of methyl radicals via multiple electron impact excitations (9-10) and/or from the coupling of atomic $\mathrm{C}$ and $\mathrm{H}$ radical (11) formed through extensive dissociation of methane (12).

Fig. 3 Optical emission spectrum for a gas mixture of $10 \%$ hexane in helium in the presence of plasma at $3 \mathrm{~W}$ and at ambient conditions. The HR 4000 spectrometer was responsive from 200 to $1,100 \mathrm{~nm}$ with a resolution of $0.04 \mathrm{~nm}$

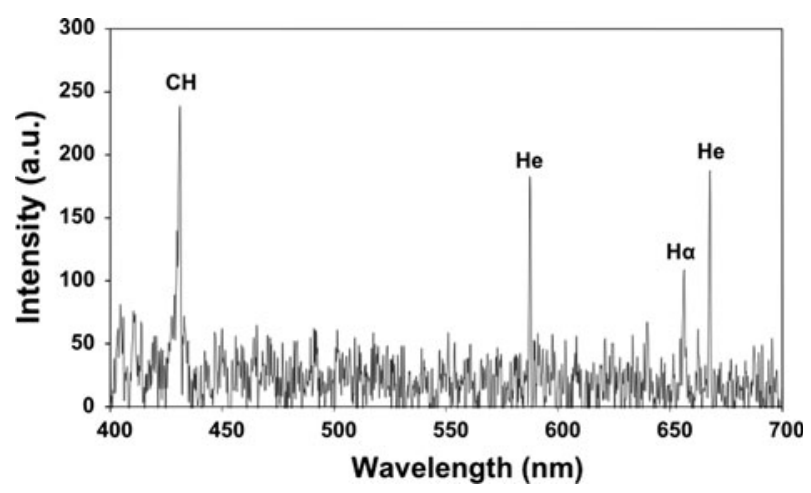




$$
\begin{aligned}
& \mathrm{CH}_{3}^{\bullet}+\mathrm{e}^{-} \rightarrow \mathrm{CH}_{2}^{\bullet}+\mathrm{H}^{\bullet}+\mathrm{e}^{-} \\
& \mathrm{CH}_{2}^{\bullet}+\mathrm{e}^{-} \rightarrow \mathrm{CH}^{\bullet}+\mathrm{H}^{\bullet}+\mathrm{e}^{-} \\
& \mathrm{C}+\mathrm{H}^{\bullet} \rightarrow \mathrm{CH}^{\bullet} \\
& \mathrm{CH}_{4}+\mathrm{e}^{-} \rightarrow \mathrm{C}+4 \mathrm{H}^{\bullet}+\mathrm{e}^{-}
\end{aligned}
$$

$\mathrm{CH}^{\bullet}$ radicals further follow predominantly two reactions; (1) Dimerization of $\mathrm{CH}^{\bullet}$ radicals lead to formation of $\mathrm{C}_{2} \mathrm{H}_{2}$, and (2) reaction with oxygen lead to $\mathrm{CO}_{2}$. Experiments studying the influence of oxygen concentrations during oxidative conversion of hexane in the plasma reactor [16], showed dramatic decrease in $\mathrm{C}_{2} \mathrm{H}_{2}$ formation with addition of oxygen in the feed. Since carbon balance in our experiments were relatively good $( \pm 10 \%)$ and experiments were carried out in the presence of oxygen, it is less likely that $\mathrm{CH}^{\bullet}$ is converted to coke. It is essential to note that gas phase radical chemistry is very complex and $\mathrm{CH}^{\bullet}$ radicals can also possibly follow various other reaction routes.

Figure 4 presents the selectivities to various products obtained from oxidative conversion of hexane in the plasma empty reactor. Temperature has a clear influence on the product distribution. At $500^{\circ} \mathrm{C}$, significant formation of $\mathrm{C}_{6}{ }^{+}$products was observed. These products were not precisely identified at molecular level due to limitation of the micro GCs, but their presence indicates the coupling of the $\mathrm{C}_{1}-\mathrm{C}_{5}$ radicals subsequent to their formation from dissociation of hexane (13). At $600^{\circ} \mathrm{C}$, however, the formation of less $\mathrm{C}_{6}{ }^{+}$ products and more $\mathrm{C}_{3}-\mathrm{C}_{5}$ olefins was observed. This indicates that at this temperature coupling reactions of $\mathrm{C}_{1}-\mathrm{C}_{5}$ radicals occur to a lesser extent. $\mathrm{C}-\mathrm{C}$ bond formation is exothermic hence favored at the lower temperatures. In agreement, during the oxidative conversion of methane, ethane and propane in a plasma-micro reactor [14, 15], coupling reactions and formation of hydrocarbons with carbon numbers higher than the feed were observed at lower temperatures.

$$
\mathrm{C}_{x} \mathrm{H}_{2 x+1}^{\bullet}+\mathrm{C}_{y} \mathrm{H}_{2 y+1}^{\bullet} \rightarrow \mathrm{C}_{n} \mathrm{H}_{2 n+2} \quad x, y=1-5, \quad n=\geq 6
$$

At $500^{\circ} \mathrm{C}$, significant formation of acetylene and ethylene and lower amounts of $\mathrm{C}_{3}-\mathrm{C}_{5}$ olefins was observed (Fig. 4), i.e., $\left(\mathrm{C}_{2} \mathrm{H}_{2}+\mathrm{C}_{2} \mathrm{H}_{4}\right)>\left(\mathrm{C}_{3}^{=}-\mathrm{C}_{5}^{\overline{5}}\right)$. Acetylene formation is

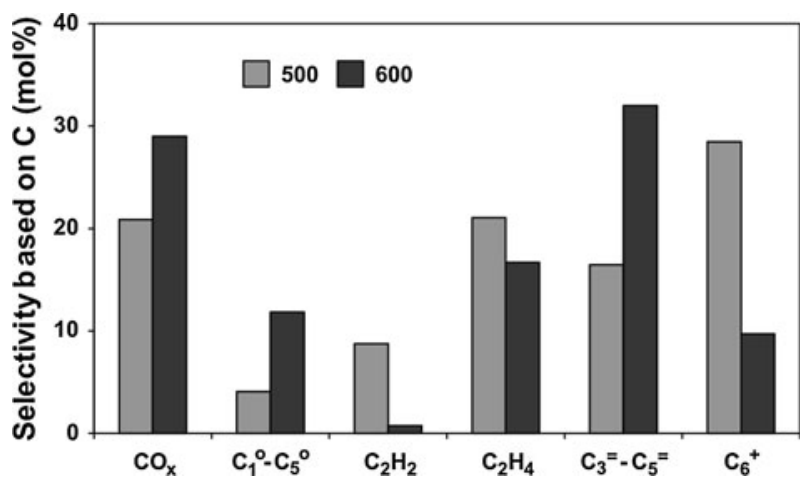

Fig. 4 Effect of temperature on the product distribution of oxidative conversion of hexane in the presence of plasma. Hexane conversions: $29 \mathrm{~mol} \%\left(500^{\circ} \mathrm{C}\right)$ and $31 \mathrm{~mol} \%\left(600^{\circ} \mathrm{C}\right)$. Reaction conditions: $100 \mathrm{ml} / \mathrm{min}$, $10 \%$ hexane, $8 \%$ oxygen and balance helium 
strong evidence of plasma chemistry. Two routes for formation of acetylene have been proposed in literature $[16,20]$. In addition to dimerization of $\mathrm{CH}^{\bullet}$ radicals discussed above, acetylene is also formed through the extensive dehydrogenation of ethane (14).

$$
\mathrm{C}_{2} \mathrm{H}_{6} \rightarrow \mathrm{C}_{2} \mathrm{H}_{4} \rightarrow \mathrm{C}_{2} \mathrm{H}_{2}
$$

At $600^{\circ} \mathrm{C}$, however, a higher ratio of $\left(\mathrm{C}_{3}^{=}-\mathrm{C}_{5}^{=}\right) /\left(\mathrm{C}_{2} \mathrm{H}_{2}+\mathrm{C}_{2} \mathrm{H}_{4}\right)$ was observed than at $500^{\circ} \mathrm{C}$. This indicates that at this temperature the reaction of $\mathrm{C}_{1}-\mathrm{C}_{5}$ radicals with molecular oxygen to olefins is more favored (15).

$$
\mathrm{C}_{n} \mathrm{H}_{2 n+1}^{\bullet}+\mathrm{O}_{2} \rightarrow \mathrm{C}_{n} \mathrm{H}_{2 n}+\mathrm{HOO}^{\bullet} \quad n=1-5
$$

Oxidative conversion of hexane over $\mathrm{Li} / \mathrm{MgO}$ catalyst

In the case of $\mathrm{Li} / \mathrm{MgO}$ catalyst, $\left[\mathrm{Li}^{+} \mathrm{O}^{-}\right]$defect sites are responsible for catalytic activity [3, 4, 8-11]. Oxidative conversion of hexane, thus, involves hexane activation via homolytic scission of $\mathrm{C}-\mathrm{H}$ bond on the $\left[\mathrm{Li}^{+} \mathrm{O}^{-}\right]$sites, forming a hexyl radical (16) [13].

$$
\mathrm{C}_{6} \mathrm{H}_{14}+\mathrm{Li}^{+} \mathrm{O}^{-} \rightarrow \mathrm{C}_{6} \mathrm{H}_{13}^{\bullet}+\mathrm{Li}^{+} \mathrm{OH}^{-}
$$

Figure 5 shows the product distribution obtained from the oxidative conversion of hexane over $\mathrm{Li} / \mathrm{MgO}$ catalyst at 500 and $600^{\circ} \mathrm{C}$. At $500^{\circ} \mathrm{C} \mathrm{Li} / \mathrm{MgO}$ catalyst showed high selectivity to combustion products $(75 \mathrm{~mol} \%)$ and only $21 \mathrm{~mol} \%$ of total olefins $\left(\mathrm{C}_{2}^{=}-\mathrm{C}_{5}^{\bar{E}}\right)$. In the oxidative conversion of lower alkanes/alkenes over $\mathrm{MgO}$, the interaction of hydrocarbons with $\mathrm{O}^{2-}$ sites of $\mathrm{MgO}$ forming surface alkoxides as precursors for $\mathrm{CO}_{x}$, has been reported by Aika and Lunsford [23, 24]. Similarly, in the oxidative conversion of hexane over $\mathrm{Li} / \mathrm{MgO}$, the high selectivity to combustion products, especially at the low temperature $\left(500^{\circ} \mathrm{C}\right)$, has been shown by us [13] to be due to the adsorption of the intermediate radicals on $\mathrm{O}^{2-}$ sites of $\mathrm{MgO}$, and their consecutive transformation to $\mathrm{CO}_{\mathrm{x}}$ via molecular oxygen. At the higher temperature $\left(600^{\circ} \mathrm{C}\right)$, however, cracking and olefin formation were more favored $\left(62 \mathrm{~mol} \%\right.$ of $\mathrm{C}_{2}^{=}-\mathrm{C}_{5}^{\overline{\bar{n}}}$ and $28 \mathrm{~mol} \%$ of $\mathrm{CO}_{\mathrm{x}}$ ). This is due to the high temperatures favoring desorption of radicals formed by hydrogen abstraction, and limiting reaction with surface oxygen for alkoxide formation.

Unlike in the presence of plasma, $\mathrm{C}_{2} \mathrm{H}_{2}$ or $\mathrm{C}_{6}{ }^{+}$products were not observed here. Both at 500 and $600^{\circ} \mathrm{C}$ selectivities to $\mathrm{C}_{3}-\mathrm{C}_{5}$ olefins were higher than those to $\mathrm{C}_{2} \mathrm{H}_{4}\left(\mathrm{C}_{3}^{=}-\mathrm{C}_{5}^{\overline{ }}>\mathrm{C}_{2}^{\bar{\nu}}\right)$

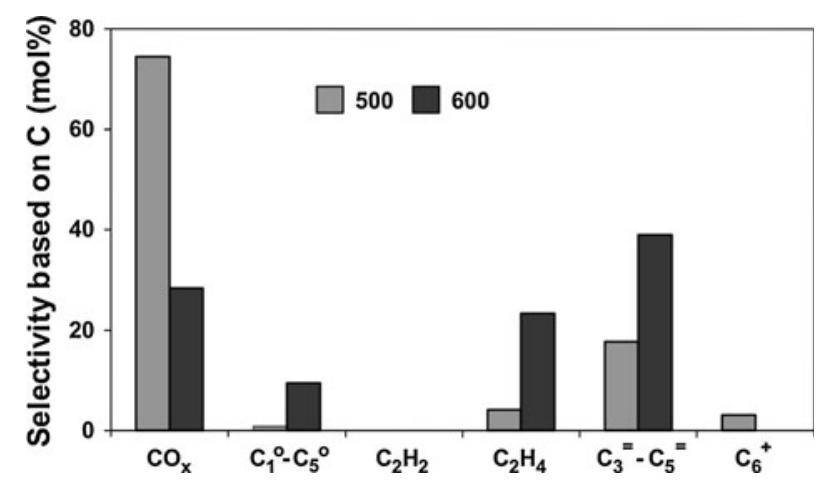

Fig. 5 Effect of temperature on the product distribution of oxidative conversion of hexane over $\mathrm{Li} / \mathrm{MgO}$ catalyst. Hexane conversions: $7 \mathrm{~mol} \%\left(500^{\circ} \mathrm{C}\right)$ and $31 \mathrm{~mol} \%\left(600^{\circ} \mathrm{C}\right)$. Reaction conditions: $100 \mathrm{ml} / \mathrm{min}$, $10 \%$ hexane, $8 \%$ oxygen and balance helium. WHSV $=3.08 \mathrm{~h}^{-1}$ 
which is an indication of role for $\mathrm{Li} / \mathrm{MgO}$ in cracking and olefin distribution, as homogeneous cracking would yield higher amounts of ethylene than higher olefins $\left(C_{3}^{=}-C_{5}^{\bar{z}}\right)$. In the oxidative conversion of hexane over $\mathrm{Li} / \mathrm{MgO}$, we proposed, based on experimental results [13] and similar to propositions by Sinev [25], the preference of the $\left[\mathrm{O}^{-}\right]$sites of $\mathrm{Li} / \mathrm{MgO}$ for hydrogen abstraction from a secondary carbon atom in hexane. This increases the probability of formation of iso-hexyl radicals. $\beta$-scission of iso-hexyl radicals yields preferentially more of $\mathrm{C}_{3}-\mathrm{C}_{5}$ olefins than ethylene.

Oxidative conversion of hexane in the situations discussed so far i.e., (1) in the presence of plasma without catalyst and (2) in the presence of $\mathrm{Li} / \mathrm{MgO}$ catalyst without plasma, however, yields even at the higher temperature $\left(600^{\circ} \mathrm{C}\right)$ limited $\mathrm{C}_{2}-\mathrm{C}_{5}$ olefins $(\sim 18 \mathrm{~mol} \%)$ due to formation of $\mathrm{CO}_{x}(\sim 28 \mathrm{~mol} \%)$. [ $\left.\mathrm{Li}^{+} \mathrm{O}^{-}\right]$sites have a strong affinity for $\mathrm{H}^{\bullet}$ abstraction, and since presence of plasma (1) enhances formation of hydrocarbon radicals and (2) abstraction of $\mathrm{H}^{\bullet}$ from a hydrocarbon radical leads to olefins, combination of plasma with $\mathrm{Li} / \mathrm{MgO}$ may be useful. In an attempt to further increase olefin yields, i.e., enhance both hexane conversions and selectivities to total olefins $\left(C_{2}^{=}-C_{5}^{\bar{E}}\right)$, the integrated plasma- $\mathrm{Li} / \mathrm{MgO}$ system is studied for the oxidative conversion of hexane.

Integrated plasma- $\mathrm{Li} / \mathrm{MgO}$ for the oxidative conversion of hexane

Figure 6 presents hexane conversions in the absence of plasma with $\mathrm{Li} / \mathrm{MgO}$ catalyst $(\mathrm{Li} / \mathrm{MgO})$, and in the presence of plasma in each of the following systems: (1) an empty reactor $\left(\mathrm{P} \_\mathrm{ER}\right),(2)$ a reactor packed with catalyst particles $\left(\mathrm{P} \_\mathrm{Li} / \mathrm{MgO}\right)$ and $(3)$ a reactor packed with quartz inert particles (P_Quartz). Results of experiments with quartz inert particles were included mainly for comparison.

At $500^{\circ} \mathrm{C}$ the integrated plasma- $\mathrm{Li} / \mathrm{MgO}$ system resulted in higher hexane conversions than the cumulative conversions achieved with plasma and $\mathrm{Li} / \mathrm{MgO}$ separately, showing synergy. This effect was not observed at $600^{\circ} \mathrm{C}$, due to depletion of oxygen $\left(\mathrm{O}_{2}\right.$ conversion $=100 \%$ ) from reaction stream limiting hexane conversions.

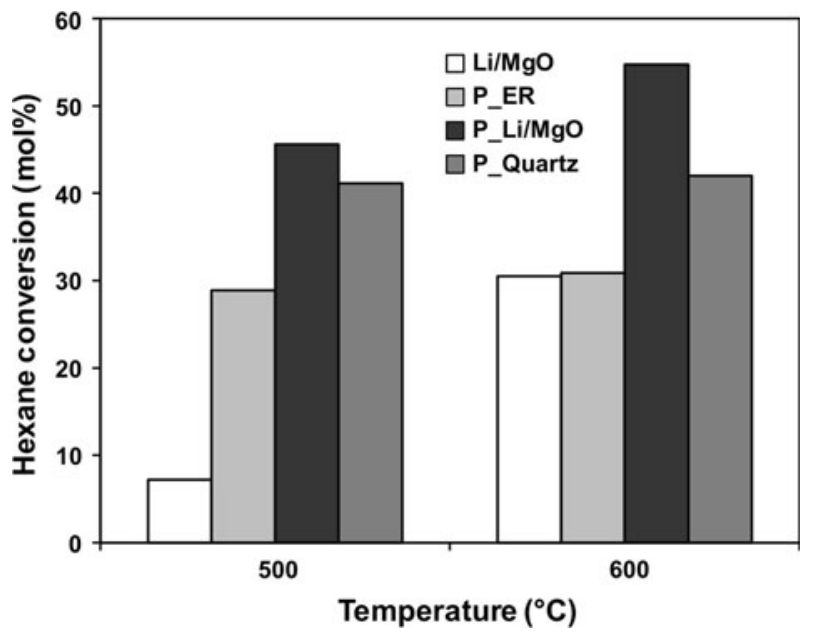

Fig. 6 Hexane conversions with the systems; (1) Li/MgO, (2) P_ER, (3) P_Li/MgO, and (4) P_Quartz. Oxygen conversions (mol \%): At 500 ${ }^{\circ} \mathrm{C} ; 56(\mathrm{Li} / \mathrm{MgO}), 71$ (P_ER), 75 (P_Li/MgO), and 68 (P_Quartz) and at $600^{\circ} \mathrm{C} ; 100(\mathrm{Li} / \mathrm{MgO}), 100\left(\mathrm{P} \_\mathrm{ER}\right), 100\left(\mathrm{P} \_\mathrm{Li} / \mathrm{MgO}\right)$ and 97 (P_Quartz). Reaction conditions: $100 \mathrm{ml} /$ min, $10 \%$ hexane, $8 \%$ oxygen and balance helium. WHSV $=3.08 \mathrm{~h}^{-1}$ 
In order to explain the influence observed we will discuss two propositions: (1) Firstly, it concerns the presence of new $\left[\mathrm{O}^{-}\right]$defect sites on the surface of $\mathrm{Li} / \mathrm{MgO}$ catalyst created by UV light generated from plasma. Knozinger and co-workers [26], reported, using EPR studies, that monochromatic UV irradiation of $\mathrm{MgO}$ particles at $5.4 \mathrm{eV}(230 \mathrm{~nm})$ and $4.6 \mathrm{eV}(270 \mathrm{~nm})$ leads to the ionization of low-coordinated surface oxygen anions $\left(\mathrm{O}_{\mathrm{LC}}^{2}\right)^{-}$ in $\mathrm{MgO}$, forming a localized surface hole state $\left[\mathrm{O}^{-}\right]$and a surface-trapped electron. Moreover, they reported [27], that such surface species are as well formed from the polychromatic (200-900 nm) irradiation of $\mathrm{MgO}$ with low energy photons (3.9-1.5 eV) resulting in a different dynamics of hole and electron center signals compared to those induced with monochromatic irradiation $(282 \mathrm{~nm})$. Thus, based on studies by Knozinger and co-workers [26, 27], we propose that in our helium-oxygen-hexane system, UV light (400-700 nm) generated by plasma, as observed in the optical emission spectrum (Fig. 3), leads to the ionization of the low-coordinated surface oxygen anions $\left(\mathrm{O}_{\mathrm{LC}}^{2}\right)^{-}$in $\mathrm{MgO}$, forming a localized surface hole state $\left[\mathrm{O}^{-}\right]$and a surface-trapped electron (17).

$$
\mathrm{O}_{\mathrm{LC}}^{2-}+h v \rightarrow \mathrm{O}_{\mathrm{LC}}^{-}+\mathrm{e}^{-}
$$

These $\left[\mathrm{O}^{-}\right]$defect sites created by the plasma, similar to the $\left[\mathrm{Li}^{+} \mathrm{O}^{-}\right]$sites, can also enhance $\mathrm{H}^{\bullet}$ abstraction from hexane forming hexyl radicals. (2) Secondly, we explain the synergistic effect by the accelerated gas phase radical chemistry due to the higher permittivity of $\mathrm{Li} / \mathrm{MgO}$ (dielectric constant of $\mathrm{MgO}=9.7$ [28]) in comparison to that of plasma (dielectric constant of plasma $<1$ [29]) in the empty reactor. The relative permittivity of a dielectric barrier can strongly determine the amount of charge that can be stored for a certain value of applied electric field [30]. The higher the number of charges transferred, the higher is the number of electron impact excitations of hexane molecules [31]. The presence of $\mathrm{Li} / \mathrm{MgO}$ particles would also, additionally, influence the strength of the electric field. Kang et al. [32] studied the influence of the ferroelectric pellets on the discharge characteristics of dielectric barrier discharges (DBD). They reported that the presence of ferroelectric pellets in plasma can create a non-uniform stronger electric field. This effect created by the packing material, can result in an increase in the average electron energy. Consequently, the number of electron impact dissociations of hexane molecules increases resulting in improved hexane conversions.

Table 1 shows the influence of plasma on the selectivities to various products during the oxidative conversion of hexane over the $\mathrm{Li} / \mathrm{MgO}$ catalyst. At both temperatures, application of plasma improved the product distribution resulting in a considerable increase in the formation of total olefins $\left(\mathrm{C}_{2}^{=}-\mathrm{C}_{5}^{\overline{ }}\right)$ and a decrease in formation of $\mathrm{CO}_{x}$. In accordance to our earlier suggestions of alkoxides as precursors to combustion [13], it is possible that in the $\mathrm{P} \_\mathrm{Li} / \mathrm{MgO}$ system, the presence of new $\left[\mathrm{O}^{-}\right]$defect sites created from the photo-excitation

Table 1 Selectivity to various products with $\mathrm{Li} / \mathrm{MgO}$ in the absence and the presence of plasma

Reaction conditions: $100 \mathrm{ml} / \mathrm{min}$, $10 \%$ hexane, $8 \%$ oxygen and balance helium.

$\mathrm{WHSV}=3.08 \mathrm{~h}^{-1}$

\begin{tabular}{|c|c|c|c|c|}
\hline & $\mathrm{Li} / \mathrm{MgO}$ & P_Li/MgO & $\mathrm{Li} / \mathrm{MgO}$ & P_Li/MgO \\
\hline$T\left({ }^{\circ} \mathrm{C}\right)$ & \multicolumn{2}{|c|}{500} & \multicolumn{2}{|c|}{600} \\
\hline \multicolumn{5}{|c|}{ Selectivity (mol\%) } \\
\hline $\mathrm{COx}$ & 75.0 & 30.5 & 28.4 & 19.0 \\
\hline $\mathrm{C}_{1}{ }^{\circ}-\mathrm{C}_{5}{ }^{\circ}$ & 0.8 & 5.1 & 9.3 & 16.9 \\
\hline $\mathrm{C}_{2} \mathrm{H}_{2}$ & - & 16.7 & - & 0.4 \\
\hline $\mathrm{C}_{2}^{=}-\mathrm{C}_{5}^{\bar{E}}$ & 21.2 & 43.9 & 62.3 & 63.7 \\
\hline $\mathrm{C}_{6}^{+}$ & 3.0 & 3.8 & - & - \\
\hline
\end{tabular}


of the $\mathrm{O}^{2-}$ sites of $\mathrm{MgO}$, minimizes the unselective interaction of radicals with the latter for alkoxide formation, thus minimizing combustion.

Results discussed above indicate that combination of plasma and $\mathrm{Li} / \mathrm{MgO}$ catalyst during the oxidative conversion of hexane is advantageous resulting in significantly higher hexane conversions and higher selectivities to olefins. However, it is crucial to investigate the contribution of the catalyst surface in both hexane activation and olefin formation when plasma chemistry is occurring.

At $500^{\circ} \mathrm{C}$, the similarity in hexane conversions with both the catalyst and quartz systems (Fig. 6) indicates less significant contribution from the catalyst in hexane conversion at this temperature. The higher conversions achieved with the presence of a dielectric material ( $\mathrm{Li} / \mathrm{MgO}$ catalyst and quartz inert) compared to the plasma reactor (P_ER), is thus due to accelerated gas phase chemistry as result of increase in both permittivity and electron energy with the introduction of the packing material. However, at $600^{\circ} \mathrm{C}$, hexane conversion from the $\mathrm{P}_{-} \mathrm{Li} / \mathrm{MgO}$ was significantly higher than that from $\mathrm{P}_{-} \mathrm{Quartz}$ system. This indicates that at this temperature there is more contribution from the catalytic defect sites $\left(\left[\mathrm{O}^{-}\right]\right)$in hexane activation.

Figure 7 presents the product distribution from the oxidative conversion of hexane at $500^{\circ} \mathrm{C}$ in the systems: (1) plasma empty reactor (P_ER), (2) plasma- Li/MgO (P_Li/MgO) and (3) plasma-quartz inert (P_Quartz). Compared to both P_ER and P_Quartz systems, $\mathrm{P} \_\mathrm{Li} / \mathrm{MgO}$ resulted in less formation of $\mathrm{C}_{6}{ }^{+}$products, and more of combustion products. This is mainly explained, as discussed earlier, by the unselective interaction of intermediate radicals with the $\mathrm{O}^{2-}$ sites of $\mathrm{MgO}$, enhancing combustion and minimizing coupling reactions. Both the catalyst and quartz systems resulted in significantly higher $\mathrm{C}_{2} \mathrm{H}_{2}$ formation than the empty reactor. It is reported by Kado et al. [22] that extent of $\mathrm{C}_{2} \mathrm{H}_{2}$ formation depends on the concentration of $\mathrm{CH}$ radicals; thus depends on the extent of dissociation and dehydrogenation reactions via electron impacts. In agreement, the high selectivities to $\mathrm{C}_{2} \mathrm{H}_{2}$ observed for both catalyst and quartz systems are due to the increase in extent of electron impact excitations as result of increase in permittivity and electron energy with the introduction of the packing material.

The olefin distribution, i.e., $\left(\mathrm{C}_{2} \mathrm{H}_{2}+\mathrm{C}_{2} \mathrm{H}_{4}\right)>\left(\mathrm{C}_{3}^{-}-\mathrm{C}_{5}^{\overline{-}}\right)$ for the above three systems (Fig. 7) strongly suggests that at this temperature plasma chemistry is more dominant.

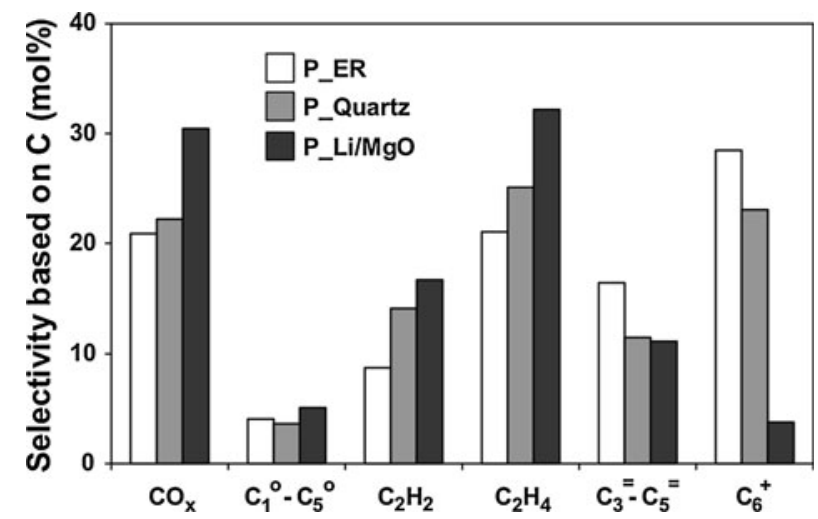

Fig. 7 Product distribution of oxidative conversion of hexane at $500^{\circ} \mathrm{C}$, with (1) P_ER (2) P_Quartz and (3) P_Li/MgO systems. Reaction conditions: $100 \mathrm{ml} / \mathrm{min}, 10 \%$ hexane, $8 \%$ oxygen and balance helium. WHSV $=3.08 \mathrm{~h}^{-1}$ 
Further, to gain insight on the contribution of $\mathrm{Li} / \mathrm{MgO}$ catalyst in hexane activation and in controlling olefin formation, a different reactor configuration with $\mathrm{Li} / \mathrm{MgO}$ downstream to plasma (Fig. 1.d) was investigated and compared to gas phase non-catalytic reactions in an empty reactor as in Fig. 1c. Results of experiments with this reactor configuration at $500^{\circ} \mathrm{C}$ (Table 2) confirm the low contribution of the catalyst in hexane activation and in olefin formation. At this temperature the catalyst downstream to plasma ( $\left.\mathrm{PB} \_\mathrm{Li} / \mathrm{MgO}\right)$ showed slightly lower hexane conversion due to quenching and similar selectivity to $\mathrm{C}_{2}-\mathrm{C}_{5}$ olefins, compared to the plasma reactor in absence of the catalyst (P_ER) (Fig. 1c). Thus, at $500^{\circ} \mathrm{C}$, plasma chemistry is more dominant, where hexane activation in gas phase via electron impact excitations and collisions with $\mathrm{O}\left({ }^{3} \mathrm{P}\right)$ atoms $(1-7)$ is a more significant pathway.

Figure 8 presents the product distribution at $600^{\circ} \mathrm{C}$ of the three systems: (1) plasma empty reactor (P_ER), (2) plasma- $\mathrm{Li} / \mathrm{MgO}\left(\mathrm{P} \_\mathrm{Li} / \mathrm{MgO}\right)$ and (3) plasma-quartz inert (P_Quartz). Similar as in $\mathrm{P} \_$ER, acetylene formation in the $\mathrm{P} \_\mathrm{Li} / \mathrm{MgO}$ system was minimal mainly due to complete oxygen consumption $\left(\mathrm{O}_{2}\right.$ conversion $\left.=100 \%\right)$. In the quartz system, as oxygen was not completely consumed $\left(\mathrm{O}_{2}\right.$ conversion $\left.=97 \mathrm{~mol} \%\right), \mathrm{C}_{2} \mathrm{H}_{2}$ formation was still observed. We speculate that in oxygen depleting conditions, hence in absence of $\mathrm{HO}_{2}^{\bullet}$ chain propagators, $\mathrm{CH}^{\bullet}$ radicals act as the main chain propagators and react further with intermediate radicals enhancing olefin formation.

Table 2 Influence of catalyst downstream to plasma zone

\begin{tabular}{llrc}
\cline { 2 - 3 } & Conversion (mol\%) & & \\
& $\mathrm{C}_{6} \mathrm{H}_{14}$ & 23.2 & 20.3 \\
& $\mathrm{O}_{2}$ & 72.1 & 92.3 \\
& Selectivity (mol\%) & & \\
& $\mathrm{CO}_{x}$ & 20.0 & 54.7 \\
& $\mathrm{C}_{1}^{\mathrm{o}-\mathrm{C}_{5}^{\mathrm{o}}}$ & 2.3 & 3.6 \\
& $\mathrm{C}_{2} \mathrm{H}_{2}$ & 5.3 & 10.5 \\
Reaction conditions: $100 \mathrm{ml} / \mathrm{min}$, & $\mathrm{C}_{2}^{-}-\mathrm{C}_{5}^{-}$ & 30.1 & 31.2 \\
$10 \%$ hexane, $8 \%$ oxygen and & $\mathrm{C}_{6}^{+}$ & 42.3 & - \\
balance helium. & &
\end{tabular}

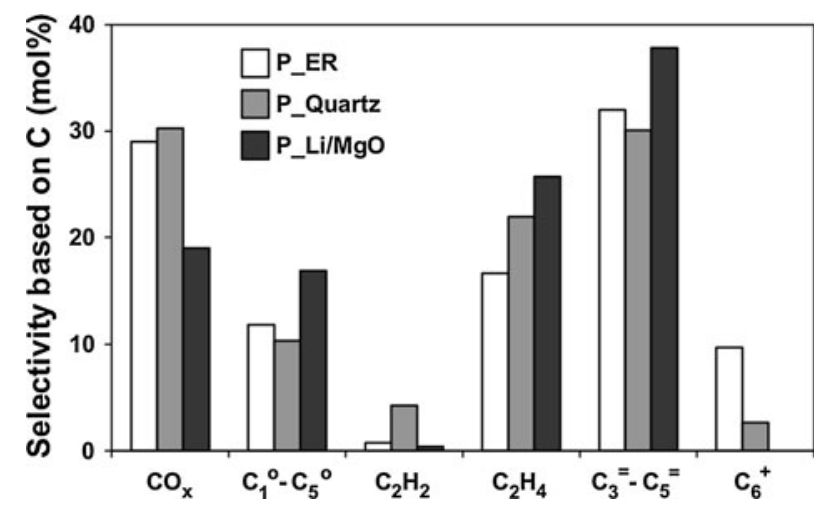

Fig. 8 Product distribution of oxidative conversion of hexane at $600^{\circ} \mathrm{C}$, with (1) $\mathrm{P}_{-} \mathrm{ER}$, (2) P_Quartz and (3) P_Li/MgO systems. Reaction conditions: $100 \mathrm{ml} / \mathrm{min}, 10 \%$ hexane, $8 \%$ oxygen and balance helium. WHSV $=3.08 \mathrm{~h}^{-1}$ 
Table 3 Influence of catalyst downstream to plasma zone

\begin{tabular}{lrc}
\hline & P_ER & PB_Li/MgO \\
\hline Conversion (mol\%) & & \\
$\mathrm{C}_{6} \mathrm{H}_{14}$ & 30.5 & 38.0 \\
$\mathrm{O}_{2}$ & 99.4 & 99.3 \\
Selectivity (mol\%) & & \\
$\mathrm{CO}_{x}$ & 27.8 & 26.1 \\
$\mathrm{C}_{1}^{\mathrm{o}}-\mathrm{C}_{5}^{\mathrm{o}}$ & 7.2 & 8.1 \\
$\mathrm{C}_{2} \mathrm{H}_{2}$ & 1.3 & 1.0 \\
$\mathrm{C}_{2}^{=}-\mathrm{C}_{5}^{=}$ & 48.2 & 64.8 \\
$\mathrm{C}_{6}{ }^{+}$ & 15.6 & - \\
\hline
\end{tabular}

Scheme 1 Mechanism of hexane cracking via $\left[\mathrm{O}^{-}\right]$sites of $\mathrm{Li} / \mathrm{MgO}$ at $600^{\circ} \mathrm{C}$

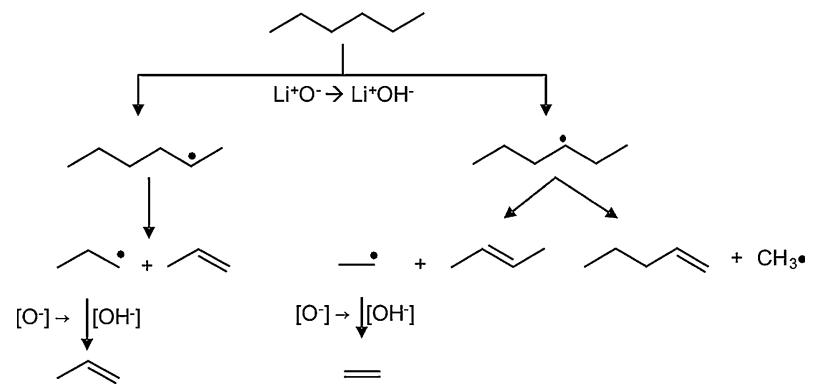

Generally at this temperature more of $\mathrm{C}_{3}-\mathrm{C}_{5}$ olefins than ethylene was observed with all the systems, i.e., $\left(\mathrm{C}_{3}^{\overline{ }}-\mathrm{C}_{5}^{\overline{\bar{n}}}\right)>\mathrm{C}_{2} \mathrm{H}_{4}$. The $\mathrm{P} \_\mathrm{Li} / \mathrm{MgO}$ system, however, resulted in considerably higher formation of $\mathrm{C}_{3}-\mathrm{C}_{5}$ olefins $(38 \mathrm{~mol} \%)$ than P_ER (32 mol\%) and P_Quartz systems $(30 \mathrm{~mol} \%)$. This indicates the role of the $\mathrm{Li} / \mathrm{MgO}$ in enhancing $\mathrm{C}_{3}-\mathrm{C}_{5}$ olefin formation.

Further, experiments with $\mathrm{Li} / \mathrm{MgO}$ downstream to plasma $\left(\mathrm{PB} \_\mathrm{Li} / \mathrm{MgO}\right)$ at $600^{\circ} \mathrm{C}$ (Table 3) showed higher hexane conversion and significantly higher $\mathrm{C}_{2}-\mathrm{C}_{5}$ olefins (64 mol\%) than with the P_ER (48 mol\%). The higher selectivity to olefins suggests consecutive interaction of alkyl radicals formed in the plasma with the active sites of $\mathrm{Li} / \mathrm{MgO}$, abstracting a second hydrogen atom from the alkyl radical forming an olefin.

Thus at $600^{\circ} \mathrm{C}$, even in presence of plasma, the surface chemistry of $\mathrm{Li} / \mathrm{MgO}$ becomes significant; i.e., (1) hexane activation via the $\left[\mathrm{Li}^{+} \mathrm{O}^{-}\right]$defect sites, forming iso-hexyl radicals, which through $\beta$-scission yield $\mathrm{C}_{3}-\mathrm{C}_{5}$ olefins, and (2) consecutive interaction of intermediate radicals with the $\left[\mathrm{O}^{-}\right]$defect sites of the catalyst leading to more olefin formation. A simplified mechanism for hexane cracking via $\left[\mathrm{O}^{-}\right]$sites of $\mathrm{Li} / \mathrm{MgO}$ at $600^{\circ} \mathrm{C}$ is illustrated in scheme 1 .

\section{Optimal Reactor Configuration for the Oxidative Conversion of Hexane}

The integrated plasma- $\mathrm{Li} / \mathrm{MgO}$ system is the optimal reactor configuration with the highest yields of $\mathrm{C}_{2}-\mathrm{C}_{5}$ olefins, as shown in Fig. 9. The introduction of the catalyst in the plasma system results in an increase in both electron density and energy; thus the number of electron impact excitations increases, leading to improved hexane conversions. Moreover, $\mathrm{UV}$ light from plasma creates new $\left[\mathrm{O}^{-}\right]$defect sites on the catalyst surface, enhancing activity and minimizing combustion reactions. 


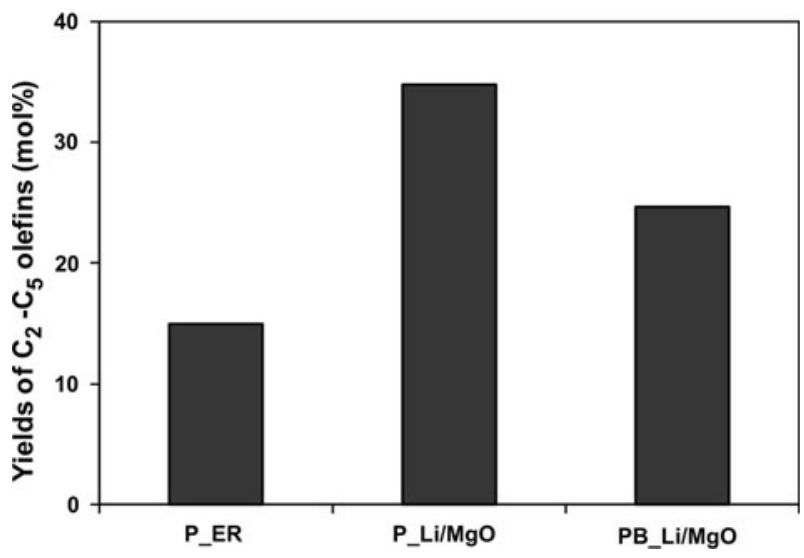

Fig. 9 Yields of $\mathrm{C}_{2}-\mathrm{C}_{5}$ olefins with different reactor configurations. Reaction conditions: $100 \mathrm{ml} / \mathrm{min}, 10 \%$ hexane, $8 \%$ oxygen and balance helium. $T=600^{\circ} \mathrm{C}$

Table 4 Estimated energy for integrated plasma-Li/MgO

\begin{tabular}{lllll}
\hline $\begin{array}{l}\text { BDE, 2ndary } \\
\mathrm{C}-\mathrm{H}(\mathrm{KJ} / \mathrm{mol})\end{array}$ & $\begin{array}{l}\text { Hexane converted } \\
(\mathrm{mol} / \mathrm{min})\end{array}$ & $\begin{array}{l}\text { Energy needed } \\
(\mathrm{J} / \mathrm{min})\end{array}$ & $\begin{array}{l}\text { Energy absorbed } \\
\text { by plasma }(\mathrm{J} / \mathrm{min})\end{array}$ & Energy loss $(\%)$ \\
\hline 394 & $1.38 \mathrm{E}-04$ & 54 & 180 & 70 \\
\hline
\end{tabular}

In order to explore the potential for industrial application of the integrated plasma$\mathrm{Li} / \mathrm{MgO}$ system, an estimation of the energy efficiency of the system was attempted. Table 4 shows a qualitative estimate of the energy efficiency of the integrated plasma$\mathrm{Li} / \mathrm{MgO}$ system. The amount of the energy absorbed by plasma (180 J/min) was compared to the amount of energy needed for dissociation of the $\mathrm{C}-\mathrm{H}$ bond in the converted hexane (54 J/min). Results indicate that only $30 \%$ of energy absorbed by plasma is utilized for hexane conversion. Inefficient utilization of plasma energy, thus, strongly suggests that further improvement in the energy efficiency of the system is required.

\section{Conclusion}

Application of both plasma and $\mathrm{Li} / \mathrm{MgO}$ catalyst in oxidative conversion of hexane results in considerable improvements both in hexane conversions and selectivities to light olefins $\left(C_{2}^{=}-C_{5}^{\bar{z}}\right)$ at a relatively low temperatures of $500-600^{\circ} \mathrm{C}$. The yields of olefins achieved with the integrated plasma-Li/MgO-catalyst are considerably higher than those achieved with $\mathrm{Li} / \mathrm{MgO}$ in absence of plasma or in plasma reactor in absence of catalyst.

The combination of plasma and catalyst results in synergy. (1) Presence of plasma creates new $\left[\mathrm{O}^{-}\right]$defect sites in the catalyst. These enhance hexane activation and moreover minimize the unselective interaction of radicals with $\mathrm{O}^{2-}$ sites of $\mathrm{MgO}$ resulting in alkoxide formation, hence minimize combustion. (2) The presence of the $\mathrm{Li} / \mathrm{MgO}$ catalyst in the plasma reactor, results in an increase in both electron-density and -energy, leading to enhanced electron impact dissociations of hexane and oxygen molecules. 
In the integrated plasma- $\mathrm{Li} / \mathrm{MgO}$ system hexane activation takes place via three main routes; (1) $\mathrm{C}-\mathrm{H}$ bond scission via the $\left[\mathrm{O}^{-}\right]$defect sites originally present as $\left[\mathrm{Li}^{+} \mathrm{O}^{-}\right]$as well as created via photo-excitation of $\mathrm{O}^{2-}$ sites of $\mathrm{MgO},(2) \mathrm{C}-\mathrm{C}, \mathrm{C}-\mathrm{H}$ bond scission by electron-impact excitation of hexane molecule with electrons, and (3) $\mathrm{C}-\mathrm{H}$ bond scission by $\mathrm{O}\left({ }^{3} \mathrm{P}\right)$ oxygen atoms formed from collisions of oxygen molecules with electrons.

Temperature influences the performance of the integrated plasma- $\mathrm{Li} / \mathrm{MgO}$ system, as illustrated by the differences in the product distribution at both temperatures. At $500^{\circ} \mathrm{C}$, significant formation of acetylene and ethylene and low formation of the high olefins $\left(C_{3}^{=}-C_{5}^{\bar{z}}\right)$ was observed. It is proposed that at this temperature plasma chemistry is more dominant. Acetylene formation is a characteristic of plasma chemistry, and can be formed via dimerization of $\mathrm{CH}$ species formed in the presence of plasma and through the extensive dehydrogenation of ethane.

At $600^{\circ} \mathrm{C}$, the reaction of intermediate radicals with oxygen to from olefins, is more favored, hence more formation of the high olefins was observed, i.e., $\left(C_{3}^{=}-C_{5}^{=}\right)>C_{2} H_{4}$. At this temperature the contribution of $\mathrm{Li} / \mathrm{MgO}$ catalyst in hexane activation and enhancing olefin formation becomes more significant. The absence of acetylene at this temperature together with oxygen depletion, suggest that oxygen depleting conditions are required to minimize acetylene formation.

Despite the significant improvements achieved with the application of plasma in the yields of $\mathrm{C}_{2}-\mathrm{C}_{5}$ olefins, the integrated plasma- $\mathrm{Li} / \mathrm{MgO}$ system still can not compete with the conventional cracking processes, due to the low energy efficiency.

Acknowledgments The authors gratefully thank ASPECT program, the Netherlands, for financial support (project number 053.62.011). The authors also acknowledge Ing. B. Geerdink and K. Altena-Schildkamp for technical support, L. Vrielink for BET measurements.

Open Access This article is distributed under the terms of the Creative Commons Attribution Noncommercial License which permits any noncommercial use, distribution, and reproduction in any medium, provided the original author(s) and source are credited.

\section{References}

1. Lin C-H, Campbell KD, Wang J-X, Lunsford JH (1986) J Phys Chem 90:534

2. Driscoll DJ, Martir W, Lunsford JH (1987) J Phys Chem 91:3585

3. Ito T, Wang J-X, Lin C-H, Lunsford JH (1985) J Am Chem Soc 107:5062

4. Xu M, Shi C, Yang X, Rosynek MP, Lunsford JH (1992) J Phys Chem 96:6395

5. Morales E, Lunsford JH (1989) J Catal 118:255

6. Cavani F, Trifiro F (1995) Catal Today 24:307

7. Landau MV, Kaliya ML, Gutman A, Kogan LO, Herskowitz M, van den Oosterkamp PF (1997) Stud Surf Sci Catal 110:315

8. Leveles L, Seshan K, Lercher JA, Lefferts L (2003) J Catal 218:307

9. Leveles L, Seshan K, Lercher JA, Lefferts L (2003) J Catal 218:296

10. Trionfetti C, Babich IV, Seshan K, Lefferts L (2006) Appl Catal A 310:105

11. Trionfetti C, Babich IV, Seshan K, Lefferts L (2008) Langmuir 24:8220

12. Cavani F, Ballarini N, Cericola A (2007) Catal Today 127:113

13. Boyadjian C, Lefferts L, Seshan K (2010) Appl Catal A 372:167

14. Trionfetti C, Agiral A, Gardeniers JGE, Lefferts L, Seshan K (2008) Chem Phys Chem 9:533

15. Trionfetti C, Agiral A, Gardeniers JGE, Lefferts L, Seshan K (2008) J Phys Chem 112:4267

16. Agiral A, Boyadjian C, Seshan K, Lefferts L, Gardeniers JGE (2010) J Phys Chem C 114:18903

17. Ahmed S, Aitani A, Rahman F, Al-Dawood A, Al-Muhaish F (2009) Appl Catal A 339:1

18. Harling AM, Demidyuk V, Fischer SJ, Whitehead JC (2008) Appl Catal B 82:180

19. Zhu X, Huo P, Zhang Y-P, Cheng D-G, Liu C-J (2008) Appl Cat B 81:132

20. Nozaki T, Muto N, Kado S, Okazaki K (2004) Catal Today 82:57 
21. Kangjun W, Xiaosong L, Hui W, Chuan S, Yang X, Amin Z (2008) Plasma Sci Tech 10:600

22. Kado S, Urasaki K, Sekine Y, Fujimoto K, Nozaki T, Okazaki K (2003) Fuel 82:229

23. Aika K-I, Lunsford JH (1977) J Phys Chem 81:1393

24. Aika K-I, Lunsford JH (1978) J Phys Chem 82:1794-1800

25. Kondratenko EV, Sinev MY (2007) Appl Catal A 325:353

26. Sterrer M, Berger T, Diwald O, Knozinger E (2003) J Am Chem Soc 125:195

27. Sterrer M, Diwald O, Knozinger E, Sushko Peter V, Shluger Alexander L (2002) J Phys Chem B $106: 12478$

28. http://clippercontrols.com/info/dielectric_constants.html\#M

29. http://farside.ph.utexas.edu/teaching/em/lectures/node100.html

30. Xu X (2001) Thin Solid Film 390:237

31. Li R, Tang Q, Yin S, SatoT (2006) Fuel Process Technol 87:617

32. Kang WS, Park JM, Kim Y, Hong SH (2003) IEEE Trans Plasma Sci 31:504 